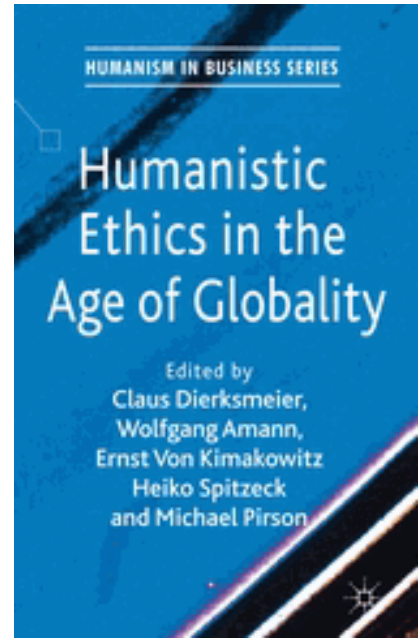

Hardback

22 Jul 2011 $£ 65.00$

9780230273276

\section{Humanistic Ethics in the Age of Globality}

\author{
Edited by: Claus Dierksmeier, Wolfgang Amann, Ernst Von \\ Kimakowitz , Heiko Spitzeck, Michael Pirson
}

Series: Humanism in Business Series

CLAUS DIERKSMEIER is associate professor for philosophy at Stonehill College, Boston, USA, with a special interest in the theory of freedom and the history of liberal thought in Europe, North and South America. He has published several books on legal, political, and religious philosophy and works currently on topics of globalization ethics and corporate social responsibility.

WOLFGANG AMMAN is the director of executive education, open enrolment and custom programs at Goethe Business School in Frankfurt, Germany and teaches on a variety of strategy and governance topics. Previously he was the principal project leader to turn the European Business School into a fully integrated university with multiple disciplines and faculties. He has also been vice-director of the executive school of the University of St.Gallen, Switzerland.

ERNST VON KIMAKOWITZ holds an MSc from the London School of Economics, UK and an award winning PhD from the University of St. Gallen, Switzerland, where he is also teaches as a guest lecturer. Following several years in the strategy practice of a large management consulting firm he works as an independent professional, providing consulting, advisory, and executive coaching services in the corporate responsibility arena to, private and public sector clients.

HEIKO SPITZECK is a professor at Fundação Dom Cabral, Brazil. Previously he was a lecturer at Cranfield University's Doughty Centre for Corporate Responsibility in the UK. He obtained his PhD in Business Ethics at the University of St. Gallen in Switzerland and held visiting scholar positions at the University of California at Berkeley and Fordham University in New York.

MICHAEL PIRSON is an assistant professor at Fordham Graduate School of Business in New York, USA, as well as a research fellow and lecturer at Harvard University, USA. Before receiving his $\mathrm{PhD}$, Michael worked in international management consulting for several years. He also gained experience in the political arena while working on Hillary Clinton's Senate campaign. Michael currently serves on the board of three social enterprises.

Through ongoing globalization managers today are faced with an array of values and codes of conduct that claim to be of relevance to their daily practice. Cultures and moral expectations differ around the globe which has resulted in the management of corporate responsibility becoming increasingly complex. Is there, however, a humanistic consensus that can bridge cultural and ethnic divides and reconcile the diverse and contrary interests of stakeholders world-wide?

The authors of this book discuss this question by exploring the rich traditions of humanistic ethics. They operate from the assumption that a concentration on the nature and the well-being of the human person could provide the requisite focus for an inter-cultural debate around normative ideals that could help both clarify and improve the often tense relationship between business and society. 


\section{Contents:}

Introduction

PRE-MODERN THEORIES

Socrates and Plato - Applying their Humanistic Views to Modern Business Ioanna Patsioti-Tsacpounidis

Aristotle's Economic Ethics Claus Dierksmeier and Michael Pirson

Stoic Humanism Maximilian Forschner

Thomas Aquinas on Business and the Fulfillment of Human Needs Claus

Dierksmeier and Anthony Celano

MODERN POSITIONS

Kant's Humanist Ethics Claus Dierksmeier

Humanistic Values in German Idealism Richard Fincham

Marx and Humanism Ulrich Steinvorth

John Stuart Mill and the Idea of a Stationary State Economy Michael Buckley CONTEMPORARY PHILOSOPHY

Habermas and his communicative perspective Suzan Langenberg

Sen and Nussbaum on Human Capabilities in Business Benedetta Giovanola

Solomon on the Role of Virtue Ethics in Business Ulrike Kirchengast

Wittgenstein and the Challenge of Global Ethics Julian Friedland

NON-WESTERN AND NON-TRADITIONAL APPROACHES

Humanistic Values in Indian and Chinese Traditions Monika Kirloskar-Steinbach

'African humanism' and a Case Study from the Swahili Coast Kai Kresse

Conclusions

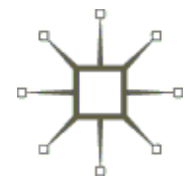




\section{ORDER FORM}

You can order online at:

www.palgrave.com

or

please return this form to:

Direct Customer Services,

Palgrave Macmillan,

Publishing Building,

Brunel Road, Houndmills,

Basingstoke, RG21 6XS, UK

Tel: $+44(0) 1256302866$

Fax: +44 (0)1256 330688

Email: orders@palgrave.com

\section{Customers in USA:}

Palgrave Macmillan, VHPS, 16365 James Madison Highway,

(US route 15), Gordonsville,

VA 22942, USA

Tel: 888-330-8477

Fax: 800-672-2054

\section{Customers in Australia:}

Customer Services,

Palgrave Macmillan,

627 Chapel Street, South Yarra, VIC 3141, Australia

Tel 1300135113 (free call) Fax 1300135103

$$
\text { Email: }
$$

customer.service@macmillan.com.au

All prices on this leaflet are correct at time of printing and are subject

to change without prior notice.

Please allow 28 days from date

of publication for delivery.

Your details may be held on file and used by us to offer you other products and services.

If you object please

contact us at the addresses above or email

optout@palgrave.com

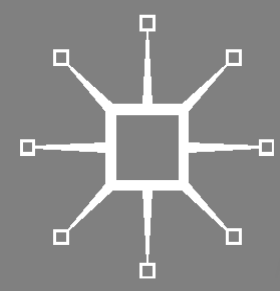

Please send me ( $\quad$ ) copies of

Title: Humanistic Ethics in the Age of Globality

Price: $£ 65.00$

ISBN: 9780230273276

Name:

Delivery Address:

Postal Code:

Country:

Email:

Telephone:

\section{POSTAGE AND PACKING}

UK orders under $£ 40$, please add $£ 3$ per order; over $£ 40$, please add $£ 4$ per order Non-UK orders under $£ 40$, add $£ 5$ per order; over $£ 40$, please add $10 \%$

\section{MAILING LIST}

Tick here [ ] if you would like to be added to our mailing list

Tick here [ ] if you would like to receive free copies of catalogues in related subjects

\section{HOW TO PAY}

[ ] I enclose a cheque payable to Palgrave Publishers Ltd for $£$

[ ] Please send me a pro-forma invoice (address supplied above)

[ ] Please charge $£$ to my

\section{Visa [ ] Mastercard [ ] American Express [ ] Switch/Maestro [ ]}

Card number:

Expires:

Cardholder name and address (if different from above):

\section{Date:}

